Research paper

\title{
Mycorrhizal symbiosis in the Paleozoic seed fern Glossopteris from Antarctica
}

\author{
Carla J. Harper ${ }^{\text {a,* }}$, Thomas N. Taylor ${ }^{\text {a }}$, Michael Krings ${ }^{\text {a,b }}$, Edith L. Taylor ${ }^{\text {a }}$ \\ a Department of Ecology and Evolutionary Biology, and Natural History Museum and Biodiversity Institute, University of Kansas, Lawrence, KS 66045-7534, USA \\ ${ }^{\mathrm{b}}$ Department für Geo- und Umweltwissenschaften, Paläontologie und Geobiologie, Ludwig-Maximilians-Universität, and Bayerische Staatssammlung für Paläontologie und Geologie, \\ Richard-Wagner-Straße 10, 80333 Munich, Germany
}

\section{A R T I C L E I N F O}

Article history:

Received 29 October 2012

Received in revised form 5 January 2013

Accepted 7 January 2013

Available online 23 January 2013

\section{Keywords:}

ecology

fossil fungi

Permian

Paris-type arbuscules

pteridosperm

Vertebraria

\begin{abstract}
A B S T R A C T
Mycorrhizal associations occur in almost all modern plant groups and are probably one of the most important forms of symbioses in the context of terrestrial ecology and evolution. Surprisingly, there is a paucity of information regarding the occurrence of mycorrhizal symbioses in extinct plant groups. We report the first evidence of endomycorrhizal associations in the seed fern order Glossopteridales based on structurally preserved (permineralized) fossils from the Permian of Antarctica. The fungus, Glomites vertebrariae sp. nov., is characterized by septate hyphae that colonize the cortical cells of Vertebraria in a serpentine or helical pattern that closely resembles modern Paris-type mycorrhizae. Also present are intercellular vesicles. The fungus is only found in young rootlets, suggesting that the mycorrhizae played an essential role during the early establishment of the roots. The discovery of this plant-fungal association provides unequivocal evidence for the antiquity of mycorrhizal associations in seed plants. In addition, it also provides further insight into the structure of Gondwanan Permian paleoecosystems. Fungal associations, together with data on the anatomy and physiology of Glossopteridales, offer insights that may help to explain the dominance of these seed ferns in the Permian of Gondwana.
\end{abstract}

(c) 2013 Elsevier B.V. All rights reserved.

\section{Introduction}

\subsection{Importance of mycorrhizal associations}

Fungi are critical in modern ecosystems, where they fill many fundamental niches, e.g., as biotrophs, mutualists, saprotrophs, necrotrophs, and parasites (Dighton et al., 2005). All major phyla of fungi (i.e., Ascomycota, Basidiomycota, Blastocladiomycota, Chytridiomycota, Glomeromycota, and Zygomycota) occur in the fossil record and appear to be morphologically conserved organisms (Lucking et al., 2009). Moreover, paleontological evidence indicates many fossil fungi performed similar roles in the bio- and geosphere as they do today, including as key associates of photosynthetic organisms ranging from microalgae to Embryophyta (e.g., Pirozynski and Malloch, 1975; Selosse and Le Tacon, 1998; Krings et al., 2012). For example, extant plants are nutritionally limited by the bioavailability of many essential macro- and micronutrients in the rhizosphere, e.g., phosphorous, nitrogen, potassium, copper, and zinc (Marschner and Dell, 1994; Peterson and Farquhar, 1994). The availability of these nutrients is strongly dependent on the chemical state that can be readily metabolized by the plant and the $\mathrm{pH}$ of the soil. Fungal hyphae can secrete acids, thus chemically reducing the surrounding soil, which transforms nutrients into a useable form for the plant. Additionally, fungal partners are beneficial because they can explore surrounding soil at reduced carbon cost

\footnotetext{
* Corresponding author. Tel.: +1 7858644255

E-mail address: charper@ku.edu (C.J. Harper).
}

for the plant due the small size of hyphae in contrast to roots (Toljander et al., 2006). By definition, mycorrhizae are symbiotic (generally mutualistic) associations between a fungus and the roots (or thalli) of a plant (Dickson, 2004; Kirk et al., 2008). The designation paramycorrhizae for colonization of thalli and shoot systems, and eumycorrhizae for colonization of roots has been introduced by paleontologists as a means to distinguish where colonization occurs in the plant since various organs containing symbionts pre-date the evolution of true roots (StrulluDerrien and Strullu, 2007). Para- and eumycorrhizal associations occur in all extant plant groups, which include bryophytes, lycophytes, sphenophytes, pteridophytes, gymnosperms, and angiosperms (Wang and Qiu, 2006). The most widespread mycorrhizal type, the arbuscular form, involves the fungal group Glomeromycota, a phylum that comprises about 200 morphospecies within 26 genera (Oehl et al., 2011; Stürmer, 2012); traditionally these fungi have been distinguished by features of the spore wall, mode of spore formation (Morton, 1988), and the use of molecular markers. This group of obligate mutualists is characterized by the presence of coenocytic mycelia, asexual reproduction through sporogenesis at the hyphal tip, and the production of arbuscules (Redecker and Raab, 2006; Schüßler and Walker, 2011). Glomus is the largest genus in the phylum with more than 70 species formally described to date (Schwarzott et al., 2001; Schüßler and Walker, 2011). One of the most distinct morphological features of Glomus sp. is the production of vesicles (lipid storage) and arbuscules within roots; other genera, such as Gigaspora and Scutellospora, form arbuscules within roots but lack vesicles (Redecker and Raab, 2006). In the glomeromycetes, the arbuscule is the point of physiological 
exchange between the plant and fungus, i.e., the plant receives the accessible form of nutrients and the fungus receives carbohydrates (hexoses) that are then converted into glycogen (Peterson and Farquhar, 1994; Smith and Read, 2008).

Arbuscules can be further divided into two morphologic groups: the Arum and Paris types. Arum-type arbuscules are highly dichotomized structures that are produced via the trunk hyphae in the lumen of a cell. Conversely, Paris-type arbuscules are coiled structures that grow in the root cortex intercellularly (Dickson, 2004); however, it has been demonstrated that the same fungus can produce either morphology depending upon on the host plant (Gerdemann, 1965; Brundrett and Kendrick, 1988, 1990). The term arbuscule literally translates to "small tree." Since the Paris-type morphology is represented by hyphae that do not dichotomize, we will refer to the Paris-type as mycorrhizal hyphae rather than arbuscules, although they are functionally equivalent to highly branched arbuscules.

\subsection{Glossopteridales - Vertebraria}

The Glossopteridales are a group of late Paleozoic seed ferns that were the dominant floral component of the Permian in Gondwana. Vertebraria, the anatomically distinctive root of Glossopteris, consists of a central zone of exarch primary xylem surrounded by two to eight radiating arms of wood, each separated by distinct lacunae (McLoughlin, 1992; Neish et al., 1993; Decombeix et al., 2009). The secondary xylem can be continuous near the periphery of the axis and typically contains distinct growth rings; a narrow band of periderm surrounds the zone of secondary xylem. In longitudinal section, the secondary xylem wedges are connected at varying intervals by transverse segments of wood that have been termed platforms, and these commonly contain a trace to a lateral root (Decombeix et al., 2009). A few crushed parenchyma cells have been identified in the hollow areas between the xylem arms and the platforms; cells are only present at early stages of development, and are essentially empty during later stages (Neish et al., 1993). Young Vertebraria rootlets are distinguished by the presence of an intact cortical layer and lack of secondary xylem (Neish et al., 1993; Decombeix et al., 2009). Although the vegetative and some of the reproductive organs of the Glossopteridales from Antarctica have been described (e.g., Taylor et al., 1989b; Pigg and Taylor, 1993; Ryberg, 2009; Ryberg et al., 2012), the fungal associations with these plants have not been studied in great detail (see below).

\subsection{Antarctic Permian fungi}

There have been a few reports of fungal remains from the Permian of Antarctica (e.g., Schopf, 1970; see 4. Permian Fungi in Taylor and Taylor (1997); Holdgate et al., 2005; Slater et al., 2012), including forms interpreted as parasitic chytrids and Glomeromycota-like chlamydospores (García Massini, 2007a, 2007b). To date, the only accounts of fungi associated with the Glossopteridales are three reports of wood-decaying fungi, in the form of fungal fragments such as hyphae in the secondary xylem of mature Vertebraria roots (Stubblefield and Taylor, 1986), and stem wood attributed to Araucarioxylon (McLoughlin, 1992) or Australoxylon (Weaver et al., 1997). In the present paper we expand the current knowledge of fungi associated with the Glossopteridales with the description of the first mycorrhizal association in roots of Vertebraria. Additionally, we provide the first evidence of mycorrhizal associations in Paleozoic seed ferns and the earliest record of Paris-type mycorrhizae in the fossil record.

\section{Materials and methods}

The fossils were collected from Skaar Ridge, $84049^{\prime} 11.8^{\prime \prime}$ S, 1630 $20^{\prime} 37.0^{\prime \prime} \mathrm{E},(2300 \mathrm{~m})$, a locality exposing Upper Permian rocks overlooking the Beardmore Glacier, Queen Alexandra Range, central Transantarctic Mountains, Antarctica (Taylor et al., 1989a). The depositional environment at this site is fluvial and the rocks are within the upper Buckley Formation (Cúneo et al., 1993). At this site, deposits include permineralized (silicified) peat containing typical glossopterid elements, including Glossopteris leaves, wood traditionally assigned to the Araucarioxylon/Dadoxylon-type (see Decombeix et al., 2010) or more recently, to Agathoxylon (e.g., Philippe, 2011; Rößler et al., in press), several reproductive structures (Taylor and Taylor, 1987; Cúneo et al., 1993; Ryberg, 2009; Ryberg et al., 2012), and Vertebraria root systems. To date, there have been no leaves or reproductive structures of non-glossopterid gymnosperms described from the Skaar Ridge peat. There are, however, some gymnosperm roots with an anatomy different from Vertebraria; these are similar to what Neish et al. (1993) described as "solid-cylinder Vertebraria." It is impossible to determine whether they represent a variation in root system anatomy within the glossopterids, or if they are the roots of a different group (Decombeix et al., 2009). As noted by Neish et al. (1993), the very young developmental stages of these roots do look very similar to the young stages of the Vertebraria roots that have only two protoxylem strands. However, in the present case we are confident that the roots in which the fungi are described are indeed Vertebraria and not the "solid-cylinder" type of roots. This is partly due to evidence that the "solid-cylinder" roots are very rare (only a few occurrences in the peat blocks from Skaar Ridge) and they occur in small distinct clusters of a few roots (i.e., not inter-mixed with Vertebraria) p.655 in Decombeix et al. (2009).

Specimens were prepared according to the standard acetate peel techniques (Joy et al., 1956; Galtier and Phillips, 1999) in order to survey material for viable areas containing fungi. Specimens were then prepared according to standard thin-section techniques with few modifications (Hass and Rowe, 1999). Pieces were mounted on microscope slides using Hillquist 2-part A-B epoxy compound and cut with a Buehler Petrothin ${ }^{\circledR}$ thin-sectioning machine to a thickness of $\sim 250 \mu \mathrm{m}$. The wafer was subsequently ground down to a thickness of $50-65 \mu \mathrm{m}$ and analyzed using a Leica DM5000B transmitted-light compound microscope. Digital images were taken with a Leica DC500 digital camera attachment and minimally processed using Adobe Photoshop CS4 Version 11.0.2 (1990-2010, Adobe Systems). Multiple micrographs of the same specimen at different focal planes were compiled to produce composite images (e.g., Bercovici et al., 2009). The images were stacked in Adobe Photoshop CS4 and specific areas were erased in subsequent focal planes to reveal the full threedimensional image seen in the thin sections. Measurements were taken using Image $1.43 \mathrm{u}$ software (Abràmoff et al., 2004). Specimens and slides are deposited in the Paleobotanical Collections, Natural History Museum and Biodiversity Institute, University of Kansas (KUPB), under specimen accession numbers $15491 \mathrm{G}$ bot, $15685 \mathrm{~A}$, slide accession numbers 23172 and 23214, and thin section slide accession numbers 26831-26385. Slides of extant Metasequoia glyptostroboides specimens used for comparison are housed in the University of Alberta Paleobotanical Collections (UAPC-ALTA).

\section{Systematic paleomycology}

Phylum: Glomeromycota C. Walker et Schuessler 2001.

Genus: Glomites Taylor, Remy, Hass et Kerp emend.

Type species: Glomites rhyniensis Taylor, Remy, Hass et Kerp 1995.

MycoBank number: MB17290.

Emended diagnosis: Fossil mycorrhizal fungi similar in basic morphology to modern Glomus; vegetative hyphae aseptate to (sparsely) septate, with $\mathrm{H}-$, Y- or right-angle branches; spores glomoid, occurring singly, 
in loose aggregates or dense clusters (possibly sporocarps?), usually within the roots or rhizomes of plants; vesicles and arbuscules may be present.

Remarks: As was often the practice in the past for fossil diagnoses, there is no separate diagnosis of the genus in the original account on Glomites (Taylor et al., 1995). Rather, the diagnosis for Glomites is indicated as being the same as the diagnosis for the type species G. rhyniensis. This, however, makes it impossible to describe additional species for Glomites. Moreover, the diagnosis for G. rhyniensis includes such precise indications as spore size, hyphal diameter and features of the arbuscular structures, which are too detailed for an adequate generic diagnosis. We, therefore, have provided a broader generic diagnosis for Glomites in this paper.

Species: Glomites vertebrariae C.J. Harper, T.N. Taylor, M. Krings et E.L. Taylor nov. sp.

MycoBank number: MB803219.

Species diagnosis: Endomycorrhizal fungus; hyphae knobby, intracellular, serpentine to helical, in some cases sinuous; transverse septa present; branching dichotomous, sporadically with swellings; within individual cells serpentine to helical hyphae $~ 4-5.5 \mu \mathrm{m}$ in diameter, forming structures similar in morphology to the physiological exchange structure seen in some extant Paris-type mycorrhizal fungi; intracellular vesicles $\sim 10-30 \mu \mathrm{m}$ in diameter, pyriform to globose, terminal, septum absent at base of vesicle.

Etymology: The specific epithet "vertebrariae" refers to the plant (Vertebraria) hosting the new fungal species.

Holotype (hic designatus): Slide 26831, Plate I, Figs. 5-7; Plate II, Figs. 1-5 this paper.

Repository: Paleobotanical Collections, Natural History Museum and Biodiversity Institute, University of Kansas (KUPB), Lawrence, Kansas, United States.

Locality: Skaar Ridge, Beardmore Glacier area, Queen Alexandra Range, central Transantarctic Mountains, Antarctica; 84 49' 11.8" S, $163^{\circ} 20^{\prime} 37.0^{\prime \prime} \mathrm{E}$.

Age: Late Permian.

Stratigraphy: Upper Buckley Formation, Victoria Group, Beacon Supergroup.

Plant host: Vertebraria (Glossopteridales, Pteridospermophyta).

Description: The matrix containing the Vertebraria rootlets is a highly heterogeneous assemblage of permineralized peat. As noted above, the silicified peat contains numerous anatomically preserved specimens including various parts of the Glossopteris plant. Mature Vertebraria roots are easily recognizable by their characteristic air spaces; many developmentally younger Vertebraria rootlets grow through these air spaces. We hypothesize that the mature, fully developed Vertebraria root was in place first, perhaps moribund or partially degraded, with the young Vertebraria roots growing through the air spaces secondarily. Rootlets range from $300 \mu \mathrm{m}$ to $1 \mathrm{~mm}$ in diameter with an average of $800 \mu \mathrm{m}$ (Plate I, 1). Evidence of fungal colonization is visible in a majority of the rootlets, and only within the cortex, where they appear in both cross and longitudinal section (Plate I, 2-4). A particularly conspicuous type of fungal hypha is found approximately between 3 and 4 cell layers below the epidermis and 2-3 cell layers from the vascular cylinder. These hyphae range from 3.5 to $5.5 \mu \mathrm{m}$ in diameter and contain irregularly spaced, perpendicular septa. They typically extend through the cortical cells intracellularly (rarely intercellularly). Intracellular hyphae are typically of ubiquitous diameter on opposite sides of host cell wall; when constricted, hyphal diameter is $\sim 3 \mu \mathrm{m}$. Some locally produce $\mathrm{H}$ branches (Plate I, 5), but more commonly, they produce Y branches (Plate I, 6); all lack septa at the points of division (Plate I, 7). Longitudinal sections also show evidence of the hyphae in the young cortical cells (Plate II, 1). Cells containing the fungus are rectangular with rounded edges and approximately $50 \mu \mathrm{m}$ long by $25 \mu \mathrm{m}$ wide. These fungi are characterized by thick hyphae that average $5 \mu \mathrm{m}$ in diameter (range $=$ 4-5.5 $\mu \mathrm{m}$; Plate II, 2) and are often confined to a mycorrhizal zone that is 2-3 cell layers thick. They extend from cell to cell intracellularly, with no visible host responses at the point where the fungus penetrates the cell wall. Hyphae also produce numerous knobs and variously shaped swellings with no septum at the base of these structures (arrow in Plate II, 2). The hyphae fill the cell lumen, by initially following the inner periphery of the cell and then forming large, loop-like coils in the interior of the cell prior to penetrating the adjacent cell (Plate II, 3). These hyphae can occur singularly and tightly coiled (Plate II, 4) within the cortical cells of the rootlets. Additionally, the hyphae that produce the coils also produce vesicles ranging from 10 to $30 \mu \mathrm{m}$ long, and are typically oblong, elongate, and rarely globose. We have been unable to find distinct septa at the base of attached vesicles, although Plate II, 5 (arrow) attachment site may also represent septa. Vesicles are typically found degraded and either attached to hyphae or isolated in the matrix (Plate II, 5-7). The cell wall of these vesicles is thin, smooth, and shows no external ornamentation.

\section{Discussion}

The seed ferns, or pteridosperms, are an artificial, highly diverse group of vascular plants that spanned the Late Devonian to possibly the Eocene (McLoughlin et al., 2008; Taylor et al., 2009). Although many seed ferns have been studied in great detail based on impression/compression specimens and/or structurally preserved fossils, and are therefore well-understood today with regard to morphology and internal organization, there are few reports on interactions of these plants with fungi, specifically mycorrhizal fungi. At this stage we are uncertain as to whether this absence is the result of a failure to adequately appreciate the occurrence of fungal endophytes in roots, or simply that these organs have not been critically examined for these associations.

\subsection{Justification of new species}

To date, three other species of Glomites have been described, i.e., Glomites rhyniensis Taylor, Remy, Hass et Kerp (Taylor et al., 1995), Glomites cycestris Phipps et Taylor (Phipps and Taylor, 1996), Glomites sporocarpoides Karatygin, Snigirevskaya, K. Demchenko et Zdebska (Karatygin et al., 2006). Among these, Glomites vertebrariae is the only specimen that does not have the Arum-type arbuscule morphology, and is instead characterized by hyphal loops similar to Paris-type morphology. The host plant is not in the species diagnosis because such fungi are morphologically indistinguishable between a range of hosts.

\subsection{Comparisons with extant fungi}

Paris-type mycorrhizal associations are broadly distributed among land plants including several groups of bryophytes and pteridophytes, Ginkgo, cycads, the conifers Podocarpaceae, Taxaceae, Cupressaceae sensu lato, and most flowering plant families (Simon et al., 1993; Taylor et al., 1995; Phipps and Taylor, 1996; Smith and Smith, 1997). There is also a wide range of variation in the degree of development of arbuscules from species to species (Smith and Smith, 1997). Studies of modern fungi suggest that arbuscule morphology 
is dependent upon the host plant; however, there are no modern analogs of seed ferns in extant ecosystems.

The morphology of the arbuscules and vesicles in the glossopteridalean Vertebraria roots described in this paper is strikingly similar to the Paris-type mycorrhizal fungus found in both fossil and extant Metasequoia roots (Konoe, 1957; Böcher, 1964; Rothwell and Basinger, 1979; Stockey et al., 2001). In extant Metasequoia glyptostroboides Hu and Cheng, 1948 (Hu and Cheng, 1948), Paris-type mycorrhizal hyphae occur in cortical cells but do not encompass the entire length of the root (Noldt et al., 2004), being restricted to a defined band at a specific level with the cortex longitudinally and radially (Plate III, 1 ). These hyphae are morphologically similar to those found in Vertebraria relative to hyphal diameter, degree of coiling, and the presence of knobs (Plate III, 2). Extant Paris-type mycorrhizal hyphae can also be found isolated and in very tight coils throughout the cortex (Plate III, 3 ). These extant fungi also produce elongated vesicles of similar dimensions and shape to those of the Permian fungus (Plate III, 4).

Like in the roots of modern and fossil Metasequoia, hyphae of the mycorrhizal fungus in Vertebraria appear to be primarily intracellular and are of the Paris-type morphology. Hyphal coils generally fill cells or are confined to the inner periphery of the cell wall, and arbuscules or mycorrhizal hyphae are both numerous and well developed. In extant M. glyptostroboides, Paris-type mycorrhizal hyphae can be found singly as in Glomites vertebrariae and do not appear to occupy a concise mycorrhizal zone. This is likely due to the ephemeral nature of arbuscules (Bonfante and Perotto, 1995) as these structures persist for only about a week at a time. Cross sections of the root at varying levels indicate that the Paris-type mycorrhizal hyphae are widely dispersed and may or may not be in close contact with vesicles. The hyphae of Glomites vertebrariae and the Paris-type mycorrhizal fungi of M. glyptostroboides are similar in having transverse septa. Although not common for glomalean fungi, it has been demonstrated that under certain conditions (e.g., damage, age, pre-penetration stages of colonization) both the intra- and extra-radical hyphae can become septate, (Gerdemann, 1955; Kinden and Brown, 1976; Giovannetti et al., 1993; Smith and Smith, 1997). Additional similarities include the production of hyphal knobs on the mycorrhizal fungi in both extant M. glyptostroboides and fossil G. vertebrariae. In extant fungi, such hyphal knobs have been hypothesized to represent the points of early branching. Other possible functions for these structures include increasing the surface area within a single cell, or perhaps representing the region of the hypha that will ultimately penetrate the cell wall. It is important to note that Gigaspora and Scutellospora sp. also produce hyphal coils and knob-like structures; however, those genera do not produce vesicles. Thus, as G. vertebrariae contains vesicles and hyphal knobs, we hypothesize that this may represent either a fungus that does not show these morphological characters in extant material or may represent an intermediate form among genera, i.e., Glomus, Gigaspora, or Scutellospora.

\subsection{Exclusion of dark septate endophytes (DSE) affinity}

Dark septate endophytes (DSE) are a diverse group of ascomyceteous anamorphic fungi that colonize root cells and tissues (Jumpponen, 2001). Based on the presence of the sparsely septate hyphae, G. vertebrariae superficially resembles extant DSE. Certain Paris-type mycorrhizal fungi, consequently, can produce sparsely septate intracellular hyphae (e.g., Bedini et al., 2000; Matekwor Ahulu et al., 2004; Wu et al., 2004). Additionally, due to an absence of several diagnostic morphological DSE characters as suggested by Jumpponen and Trappe (1998), we reject the hypothesis that the fungus in this study is a DSE. These characters include a superficial net in the root cylinder; G. vertebrariae is restricted to a specific zone in the root cylinder and does not produce a highly extensive hyphal net. The fungal hyphae are exclusively intracellular and typically hyphal diameters are consistent on either side of cell wall penetration (see Plate 1, 5) and therefore lack appressoria preceding penetrating hyphae in host cell walls as seen in DSE and penetration tubes. Finally, DSE commonly form microsclerortia and have not observed in the young Vertebraria rootlets to date. It is important to note that DSE and Paris-type mycorrhizal fungi can co-occur in host plants (e.g., Wubet et al., 2003; Kubota et al., 2004; Muthukumar et al., 2006; Dolinar and Gaberščik, 2010; Stevens et al., 2010), at this time there is no evidence for the DSE. Future studies of Vertebraria may elucidate multiple levels of plant-fungal interactions, including DSE.

\subsection{Additional fungi in Vertebraria}

There are several other types of fungal remains associated with the Vertebraria rootlets, including hyphae and spores. Hyphae are intracellular, occur within root cortical tissue, and do not appear to form coils like the hyphae described above; some of the hyphae are up to $9 \mu \mathrm{m}$ in diameter (Plate III, 5). The morphology of these structures is highly variable, ranging from upright hyphal branches (3-5 $\mu \mathrm{m})$ to truncated, enlarged vase-like units (Plate III, 6). We are uncertain as to the exact biological affinities of these hyphae; perhaps they represent some stage in the formation of coils, structures leading to the formation of mature vesicles, or some other type of reproductive stage. It is important to note that these structures are remarkably

\footnotetext{
Plate I. Anatomy and fungal features of Vertebraria.

Plate I, 1. Transverse section of two young Vertebraria roots showing intact cortex (left) and central vascular bundle. Slide 26834 ; Scale bar = $100 \mu$ m.

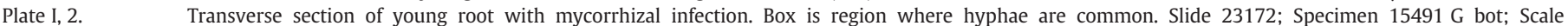
bar $=100 \mu \mathrm{m}$

Transverse section of Vertebraria rootlet showing sections of intracellular hyphae within cortical cells. Slide 26835.

Plate I, 3.

Plate I, 4.

Plate I, 5.

Plate I, 6.

Longitudinal section of cortex showing intracellular hyphae in multiple planes of section. Slide 23214; Specimen 15685 A.

Longitudinal section of rootlet showing hyphae traversing intracellularly (arrow) and H branch (HB). Slide 26831.

Hyphae with perpendicular septum (arrow). Slide 26831.

Plate I, 7. Hyphae with right angle branching; note absence of septum at base (arrow). Slide 26831.
}

Plate II. Mycorrhizal association in Vertebraria. (see on page 6)

Plate II, 1. Longitudinal section of root showing relationship between vascular bundle (VB) and Paris-type mycorrhizal zone (MZ). Boxed area enlarged in Plate II, Fig. 2. Slide 26831. Scale bar $=100 \mu \mathrm{m}$.

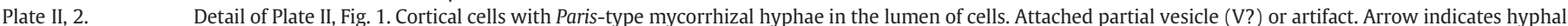
knob. Photomicrograph is partially focal stacked to show detail of attached vesicle and prominent loops in lumen. Slide 26831.

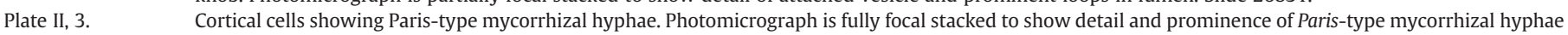
in mycorrhizal zone. Slide 26831 .

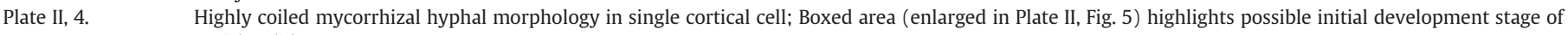
vesicle. Slide 26831.

Plate II, 5.

Plate II, 6.

Plate II, 7.
Enlargement of boxed area in Plate II, Fig. 4. Detail of attachment site (arrow) (septa?) of immature vesicle (V). Slide 26831. Scale bar $=10 \mu \mathrm{m}$.

Cortical section showing position of vesicle (V) attached to branched hypha. Slide 26832.

Detail of nearly complete intracellular vesicle (V). Slide 26832. 






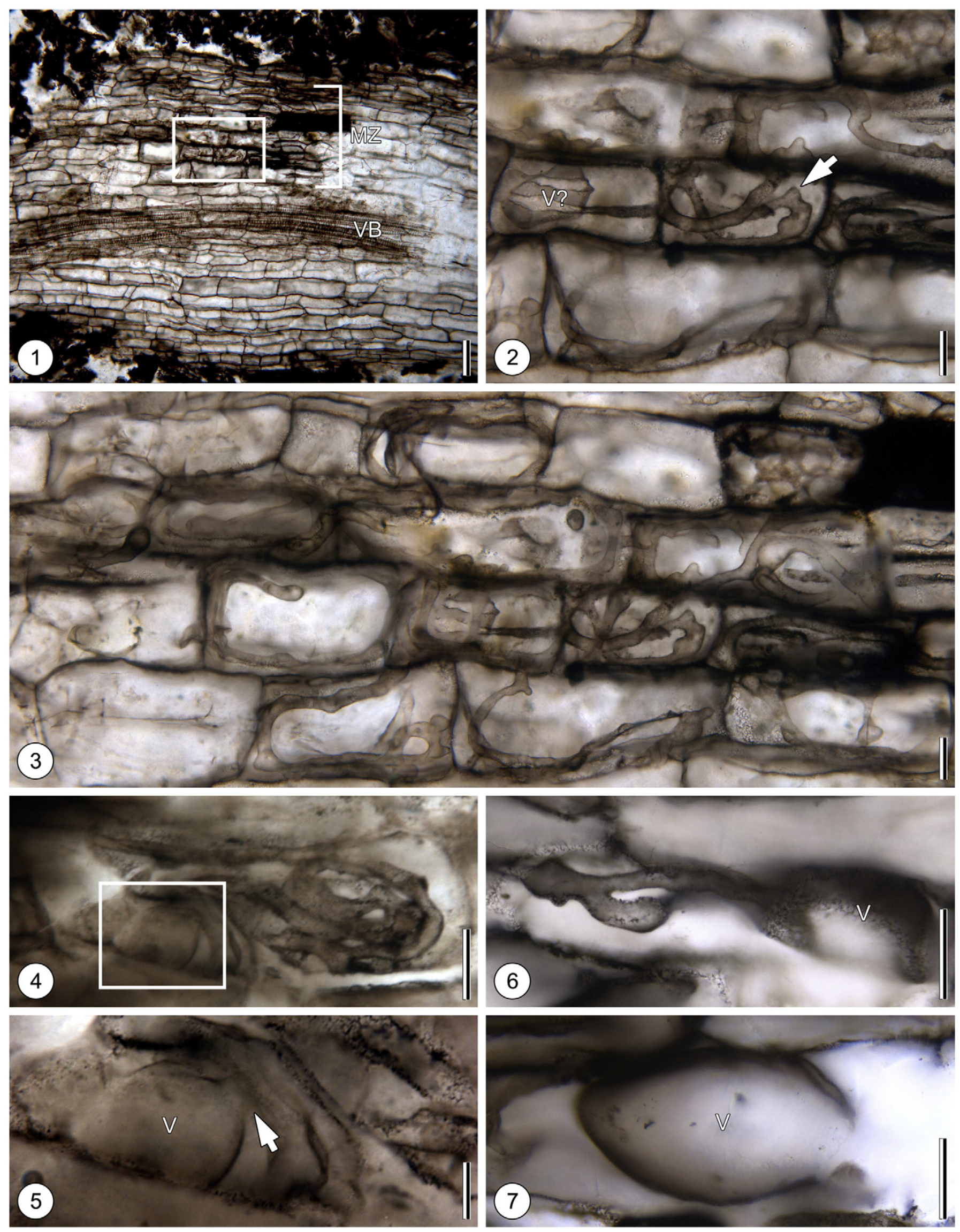

Plate II (caption on page 4). 

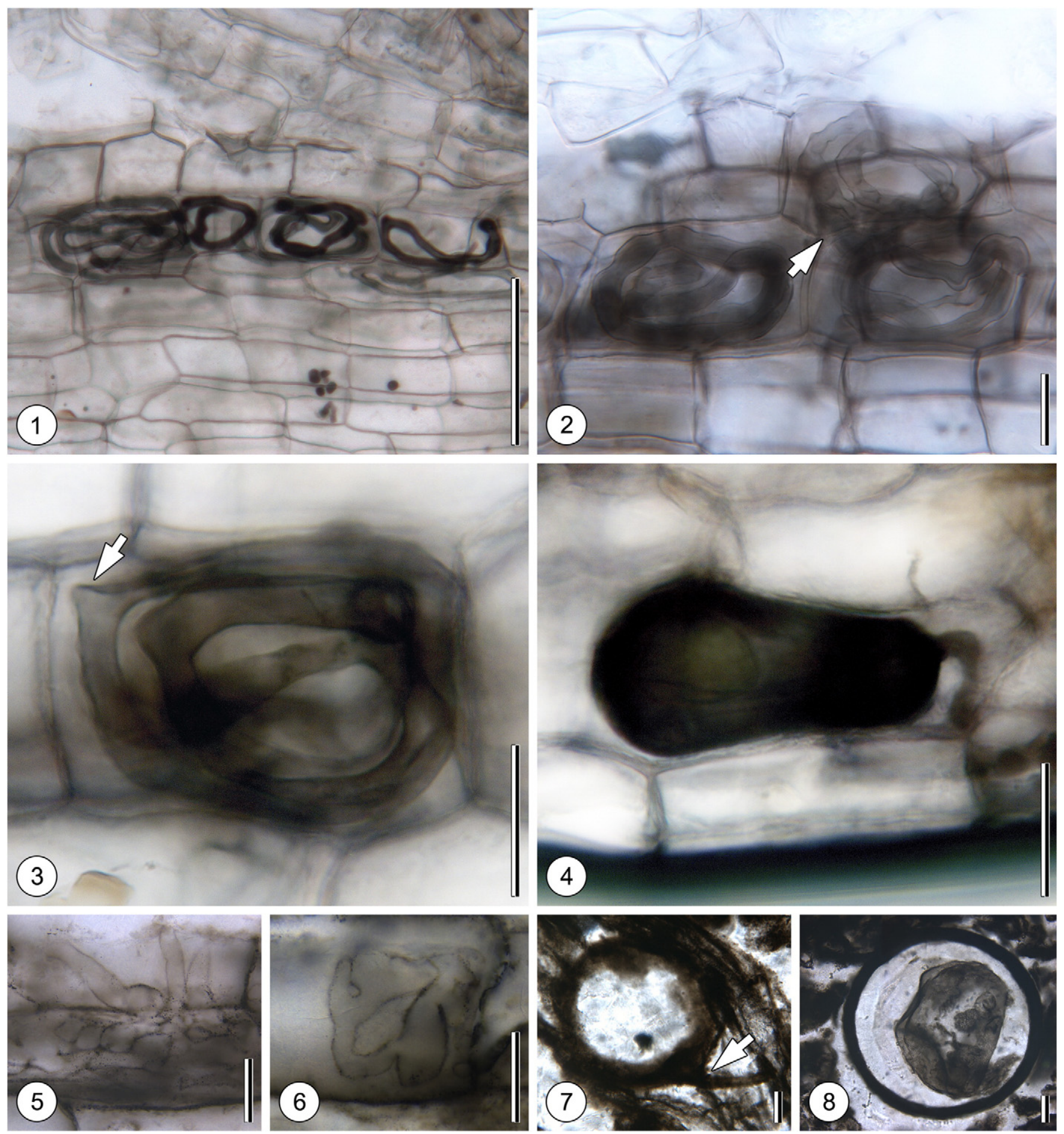

Plate III. Comparison to extant mycorrhizae and other fossil fungal components.

Plate III, 1

Plate III, 2

Plate III, 3.

Plate III, 4.

Plate III, 5 .

Plate III, 6 .

Plate III, 7. Plate III, 8.
Extant M. glyptostroboides mycorrhizal association; Note sparse distribution of arbuscules in root cortex. UAPC PAF Slide. Scale bar $=100 \mu \mathrm{m}$. Extant M. glyptostroboides mycorrhizal association showing Paris-type mycorrhizal hyphae coiled in single cell layer of cortical region; arrow indicates intracellular growth. Slide UAPC PAF Slide.

Extant M. glyptostroboides mycorrhizal association; isolated mycorrhizal coil in cell lumen. Arrow indicates hyphal knob. UAPC PAF Slide. Extant M. glyptostroboides mycorrhizal association; Elongate, oblong vesicle attached to hypha in cortex of rootlet. UAPC PAF Slide. Two cortical cells of Vertebraria with tightly packed hyphae of varying diameters. Slide 26834. Interesting hyphal morphology confined to end of Vertebraria cortical cell. Similar to fan-shaped morphology of some mycorrhizal hyphae found in pteridophytes. Slide 26834.

Asexual spore in the matrix containing the Vertebraria roots showing mycorrhizal fungus with subtending hypha (arrow). Slide 26833. Intact asexual spore from silicified peat matrix with small spherical structures in the lumen that may represent a form of mycoparasitism. Slide 26832. 
similar to the fan-shaped structures found in pteridophytes produced by certain endophytes (Fig. 38, Bonfante-Fasolo, 1984). The mycorrhizal status of these fungi remain unknown in extant studies. At this time we are uncertain if these morphologies are produced by the $G$. vertebrariae fungus. In addition, asexual spores, like those of certain glomeromycetes, are dispersed throughout the matrix, including some in close association with young Vertebraria rootlets. These spores range from 100 to $177 \mu \mathrm{m}$ in diameter and are typically globose. A thick outer opaque wall, 5 to $7 \mu \mathrm{m}$ thick, characterizes the spores. A few spores are pyriform with a blunt end-the likely site of hypha attachment. Rarely, do these spores contain a subtending hypha (Plate III, 7). Generally these spores are devoid of contents; however, one specimen contains many spherical structures with an average diameter of $23 \mu \mathrm{m}$ that are enclosed in a larger sphere (120 $\mu \mathrm{m}$ in diameter) within the spore wall (Plate III, 8). This combination of structures inside the spore may represent evidence of some type of mycoparastism. Additionally these spores are distinguishable from those described by García Massini (2007a, 2007b) due to their large size, thicker cell wall layer, absence of pore-like attachment scars, and are not found in tightly dense clusters.

\subsection{Mycorrhizal associations in the fossil record}

Evidence for mycorrhizal associations has been documented several times in the fossil record, with the oldest evidence coming from the Lower Devonian Rhynie chert (Remy et al., 1994). Overall, it is difficult to assess ecological status in fossils, especially among plant-fungal interactions. Key factors attribute to the biotrophic or mycorrhizal status of a fossil host and symbiont, which may include: presence of chlamydospores, arbuscules, zonation or spatial restriction of mycorrhizae in roots, lack of host responses, preservation of material, etc. (Taylor and Krings, 2005). Although it is impossible to definitively demonstrate physiological interactions between fossil mycorrhizal fungi and plants, based on morphological evidence and other specific characters, it is clear that this type of symbiosis is a highly conserved relationship among the land plants.

Permineralized peats of younger age from Antarctica have yielded exceptionally well preserved arbuscules. The Middle Triassic cycad Antarcticycas hosts multiple types of endomycorrhizal fungi including Gigasporites myriamyces and Glomites cycestris (Stubblefield et al., 1987a, 1987b; Phipps and Taylor, 1996). Conifer roots from the same Triassic silicified peat, including mycorrhizal nodules in the form of small spherical structures on delicate lateral roots, provide additional evidence of endomycorrhizal associations (Schwendemann et al., 2011).

\subsection{Endomycorrhizal associations in the Permian ecosystem of Antarctica}

The Glossopterdales are known to have occurred in a variety of environments, ranging from peat-forming swamps to seasonally dry, sandy floodplains (Cúneo et al., 1993; Cúneo, 1996; Isbell and Cúneo, 1996). The Glossopteris floras of Gondwana are traditionally considered to dominate coal-forming environments (e.g., McLoughlin, 1993), although in Antarctica, this floral association appears to be more widespread in other depositional environments (Cúneo et al., 1993). Many authors have suggested that the unusual anatomy of Vertebraria, which incorporates air spaces into the wood, may signal an adaptation for wetland or peat-forming environments (McLoughlin, 1993). Today, mycorrhizal associations are recorded from a diverse suite of ecosystems ranging from polar regions to swamp environments in the tropics (Tawaraya et al., 2003; Newsham et al., 2009).

Although it is more likely that Permian peat-forming environments were similar to extant swamps or marshes, it has also been hypothesized that the air spaces in Vertebraria roots may have served the same function as lacunae of extant mangrove plants (McLoughlin, 1993; Neish et al., 1993). This may suggest that at least some glossopterids have grown in saline coastal habitats. Further supporting this hypothesis is the fact that arbuscular mycorrhizae do occur with mangrove plants in high-salt and other abiotically stressed environments (Sengupta and Chaudhuri, 2002). It is important to note that even in extant plant mycorrhizal systems it is not possible to conclusively demonstrate a physiological role of these mycorrhizal fungi. Nevertheless, structural and morphological evidence justifies interpreting these fungi-root cell interaction as a mycorrhizal association.

The ontogeny and development of Vertebraria roots and rootlets was no doubt reflective of the environment in which they grew (Decombeix et al., 2009). This structure-function relationship correlates well with the ephemeral nature and evidence of mycorrhizal associations in Vertebraria, in that young rootlets contain an intact cortex and mycorrhizal zone until secondary growth occurs. The relationship is further underscored by the fact that arbuscules and vesicles have only been found within young rootlets with a well-defined cortex. This suggests that mycorrhizal associations are present in the young, developing rootlets that contain cortex and that the presence of such an association may have been critical in the promotion and early establishment of these plants in the peat-forming environment. It is impossible to know precisely the frequency of colonization of certain glossopterids with mycorrhizal associations, and whether such interactions occur only in particular environments. In extant plants, for example, fungi can shift from a mutualistic to parasitic relationship relative to a changing environment (Orcutt and Nilsen, 2000).

The high-latitude light regime of Antarctica during the Late Permian may have also influenced glossopterid mycorrhizal associations. Tree ring analysis shows that the Glossopteris plants of Antarctica are highly adapted to their environment (Taylor and Ryberg, 2007). Under certain abiotic stresses, e.g., low light intensities, mycorrhizal associations can be too carbon costly and detrimental to plant growth and development (Bereau et al., 2000). Due to the high carbon cost of mycorrhizal fungi for the plant, at times of low light or absence of light periods, the plants may have freely disassociated from the fungus (Hoeksema and Kummel, 2003). In addition to the ephemeral nature of arbuscules, this may help explain the absence of mycorrhizal fungi in some Vertebraria rootlets. In contrast, it has also been suggested that only plants that are well adapted to extreme light regimes can provide carbon for the fungus (Koltai and Kapulnik, 2010). Nevertheless, in such an environment these mycorrhizal associations may have been the critical tipping point in allowing the glossopterids to out-compete other plants in these harsh environments.

\section{Conclusions}

Although fossil plants have been reported throughout large segments of geologic time, in recent years there has been increased attention on interpreting their role in the ecosystems in which they lived. Less well understood are the relationships between these plants and the microbial component of the ecosystem, especially the fungi. It has been demonstrated that among all extant plants there are three genes that are essential to the establishment of mycorrhizal symbioses (Wang et al., 2010). This implies that all extinct plant groups had the potential for forming various types of mycorrhizal associations. Thus, the paucity of mycorrhizal associations known thus far in the fossil record for certain groups (e.g., sphenophytes, progymnosperms, gnetophytes, gingkophytes) is likely due to the fact that these associations have not been identified, perhaps due to poor preservation of anatomical details in fossils of some of these groups. In this context it is important to document the occurrences of plant-fungal interactions when found because they provide insight into the evolutionary history of these associations and may provide a calibration point for the establishment of symbioses in particular plant lineages. The discovery of mycorrhizal associations in Vertebraria contributes to a more complete understanding of the biology 
of at least some members of the Glossopteridales, and represents the first documented occurrence of a mycorrhizal association with a seed fern.

\section{Acknowledgments}

The authors gratefully acknowledge and thank the two anonymous reviewers whose detailed and thoughtful comments improved this manuscript. We are also thankful to Dr. Ari Jumpponen (Manhattan, KS, USA) for very helpful discussions on dark septate endophytes and Nora Dotzler (Munich, Germany) for technical assistance. C.J.H. thanks Dr. Benjamin Bomfleur (Lawrence, KS, USA) and Dr. Rudolph Serbet (Lawrence, KS, USA) for helpful and fruitful discussions that improved the manuscript and for technical support. Dr. Anne-Laure Decombeix (Montpellier, France) for assistance and helpful discussions on root anatomical features. The authors thank Dr. Ruth A. Stockey (Corvallis, OR, USA) for the loan of the slides of extant and extinct Metasequoia from the University of Alberta paleobotanical collections. Financial support was provided by the National Science Foundation (EAR-0949947 to T.N.T. and M.K.; OPP-0943934 to E.L.T. and T.N.T.), and the Alexander von Humboldt-Foundation (V-3.FLFDEU/1064359 to M.K.).

\section{References}

Abràmoff, M.D., Magelhães, P.J., Ram, S.J., 2004. Image Processing with Imagej. Biophotonics International 11, 36-42.

Bedini, S., Maremmani, A., Giovannetti, M., 2000. Paris-type mycorrhizas in Smilax aspera L. growing in a Mediterranean scherophyllous wood. Mycorrhiza 10, 9-13.

Bercovici, A., Hadley, A., Villanueva-Amadoz, U., 2009. Improving depth of field resolution for palynological photomicrography. Palaeontologia Electronica 12 (2) (12 pp. http://palaeo-electronica.org/2009_2/170/170.pdf (accessed May 17, 2011)).

Bereau, M., Barigah, T.S., Louisanna, E., Garbaye, J., 2000. Effects of endomycorrhizal development and light regimes on the growth of Dicorynia guianensis Amshoff seedlings. Annals of Forest Science 57, 725-733.

Böcher, T.W., 1964. Morphology of the vegetative body of Metasequoia glyptostroboides. Dansk Botanisk Arkiv 24, 1-70.

Bonfante, P., Perotto, S., 1995. Strategies of arbuscular mycorrhizal fungi when infecting host plants. New Phytologist 130, 3-21.

Bonfante-Fasolo, P., 1984. Anatomy and Morphology of VA mycorrhizae. In: Powell, C. Bagyara, D.J. (Eds.), VA Mycorrhiza. CRC Press, Boca Raton, FL, pp. 5-33.

Brundrett, M.C., Kendrick, B., 1988. The mycorrhizal status, root anatomy, and phenology of plants in a sugar maple forest. Canadian Journal of Botany 66, 1153-1173.

Brundrett, M.C., Kendrick, B., 1990. The roots and mycorrhizas of herbaceous woodland plants. I. Quantitative aspects of morphology. New Phytologist 457-468.

Cúneo, N.R., 1996. Permian phytogeography in Gondwana. Palaeogeography Palaeoclimatology Palaeoecology 125, 75-104.

Cúneo, N.R., Isbell, J.L., Taylor, E.L., Taylor, T.N., 1993. The Glossopteris flora from Antarctica: taphonomy and paleoecology. Comptes Rendus Palevol 2, 13-40.

Decombeix, A.-L., Taylor, E.L., Taylor, T.N., 2009. Secondary growth in Vertebraria roots from the Late Permian of Antarctica: a change in developmental timing. International Journal of Plant Sciences 170, 644-656.

Decombeix, A.-L., Taylor, E.L., Taylor, T.N., 2010. Epicormic shoots in a Permian gymnosperm from Antarctica. International Journal of Plant Sciences 171, 772-782.

Dickson, S., 2004. The Arum-Paris continuum of mycorrhizal symbioses. New Phytologist $163,187-200$

Dighton, J., White, J.F., Peter, O., 2005. The Fungal Community: Its Organization and Role in the Ecosystem, 3rd ed. CRC Press, Boca Raton, FL (960 pp.).

Dolinar, N.A., Gaberščik, A., 2010. Mycorrhizal colonization and growth of Phragmites australis in an intermittent wetland. Aquatic Botany 93, 93-98.

Galtier, J., Phillips, T.L., 1999. The Acetate Peel Technique. In: Jones, T.P., Rowe, N.P. (Eds.), Fossil Plants and Spores: Modern Techniques. The Geological Society, London, pp. 67-70.

García Massini, J., 2007a. A glomalean fungus from the Permian of Antarctica. International Journal of Plant Sciences 168, 673-678.

García Massini, J., 2007b. A possible endoparasitic chytridiomycete fungus from the Permian of Antarctica. Palaeontologia Electronica 10 (16A) (14 pp. (Available electronically at: http://palaeo-electronica.org/2007_3/121/index.html [last accessed May 17, 2010])).

Gerdemann, J.W., 1955. Wound-healing of hyphae in a phycomycetous mycorrhiza fungus. Mycologia 47, 916-918.

Gerdemann, J.W., 1965. Vesicular-arbuscular mycorrhizae formed on maize and tuliptree by Endogone fasciculata. Mycologia 57, 562-575.

Giovannetti, M., Sbrana, C., Avio, L., Citernesi, A.S., Logi, C., 1993. Differential hyphal morphogenesis in arbuscular mycorrhizal fungi during pre-infection stages. New Phytologist 125, 587-593.

Hass, H., Rowe, N.P., 1999. Thin Sections and Wafering. In: Jones, T.P., Rowe, N.P. (Eds.), Fossil Plants and Spores: Modern Techniques. The Geological Society, London, pp. 76-81.
Hoeksema, J.D., Kummel, M., 2003. Ecological persistence of the plant-mycorrhizal mutualism: a hypothesis from species coexistence theory. American Naturalist 162, S40-S50.

Holdgate, G.R., McLoughlin, S., Drinnan, A.N., Finkelman, R.B., Willett, J.C., Chiehowsky, L.A., 2005. Inorganic chemistry, petrography and palaeobotany of Permian coals in the Prince Charles Mountains, East Antarctica. International Journal of Coal Geology $63,156-177$.

Hu, H.H., Cheng, W.C., 1948. On the new family Metasequoiaceae and on Metasequoia glyptostroboides, a living species of the genus Metasequoia found in Szechuan and Hupeh. Bulletin of the Fan Memorial Institute of Biology 1, 153-161.

Isbell, J.L., Cúneo, N.R., 1996. Depositional framework of Permian coal-bearing strata southern Victoria Land Antarctica. Palaeogeography Palaeoclimatology Palaeoecology $125,217-238$

Joy, K.W., Willis, A.J., Lacey, W.S., 1956. A rapid cellulose peel technique in palaeobotany Annals of Botany 20, 635-637.

Jumpponen, A., 2001. Dark septate endophytes - are they mycorrhizal? Mycorrhiza 11, 207-211.

Jumpponen, A., Trappe, J.M., 1998. Dark septate endophytes: a review of facultative biotrophic rootcolonizing fungi. New Phytologist 140, 295-310.

Karatygin, I.V., Snigirevskaya, N.S., Demchenko, K.N., 2006. Species of the genus Glomites as plant mycobionts in Early Devonian ecosystems. Paleontological Journal 40, 572-579.

Kinden, D.A., Brown, M.F., 1976. Electron microscopy of vesicular-arbuscular mycorrhizae of yellow poplar. IV. Host-endophyte interactions during arbuscular deterioration. Canadian Journal of Microbiology 22, 64-75.

Kirk, P.M., Cannon, P.F., Minter, D.W., Stalpers, J.A., 2008. Ainsworth \& Bisby's Dictionary of the Fungi. CABI Publishing, Wallingford, UK (784 pp.).

Koltai, H., Kapulnik, Y., 2010. Arbuscular Mycorrhizal Symbiosis Under Stress Conditions: Benefits and Costs. In: Seckbach, J., Grube, M. (Eds.), Symbioses and Stresses. Springe Netherlands, Dordrecht, pp. 339-356.

Konoe, R., 1957. Über das Vorkommen der Vurzelpilze bie Metasequoia und den Nächst verwandten Pflanzen. Journal of the Institute of the Polytechnic, Osaka City University, series B, Biology 8, 179-184.

Krings, M., Taylor, T.N., Dotzler, N., 2012. Fungal Endophytes as a Driving Force in Land Plant Evolution: Evidence from the Fossil Record. In: Southworth, D. (Ed.), Biocomplexity of Plant-Fungal Interactions. John Wiley \& Sons, Inc, Ames IA, pp. 5-27.

Kubota, M., McGonigle, T.P., Hyakumachi, M., 2004. Co-occurrence of Arum- and Paris-type morphologies of arbuscular mycorrhizae in cucumber and tomato. Mycorrhiza 15, 73-77.

Lucking, R., Huhndorf, S., Pfister, D.H., Plata, E.R., Lumbsch, H.T., 2009. Fungi evolved right on track. Mycologia 101, 810-822.

Marschner, H., Dell, B., 1994. Nutrient uptake in mycorrhizal symbiosis. Plant and Soil 159, 89-102.

Matekwor Ahulu, E., Nakata, M., Nonaka, M., 2004. Arum- and Paris-type arbuscular mycorrhizas in a mixed pine forest on sand dune soil in Niigata Prefecture, central Honshu, Japan. Mycorrhiza 15, 129-136.

McLoughlin, S., 1992. Late Permian plant megafossils from the Bowen Basin, Queensland, Australia: part 1. Palaeontographica Abteilung B 228, 105-149.

McLoughlin, S., 1993. Plant fossil distributions in some Australian Permian non-marine sediments. Sedimentary Geology 85, 601-619.

McLoughlin, S., Carpenter, R.J., Jordan, G.J., Hill, R.S., 2008. Seed ferns survived the endCretaceous mass extinction in Tasmania. American Journal of Botany 95, 465-471.

Morton, J.B., 1988. Taxonomy of VA mycorrhizal fungi: classification, nomenclature and identification. Mycotaxon 32, 267-324.

Muthukumar, T., Senthilkumar, M., Rajangam, M., Udaiyan, K., 2006. Arbuscular mycorrhizal morphology and dark septate fungal associations in medicinal and aromatic plants of Western Ghats, Southern India. Mycorrhiza 17, 11-24.

Neish, P.G., Drinnan, A.N., Cantrill, D.J., 1993. Structure and ontogeny of Vertebraria from silicified Permian sediments in East Antarctica. Review of Palaeobotany and Palynology 79, 221-224.

Newsham, K.K., Upson, R., Read, D.J., 2009. Mycorrhizas and dark septate root endophytes in polar regions. Fungal Ecology 2, 10-20.

Noldt, G., Bauch, J., Koch, G., 2004. Structure of the fine roots of Metasequoia glyptostroboides Hu et Cheng and its adaptability to various sites. Journal of Applied Botany and Food Quality 78, 178-184.

Oehl, F., Silva, G.A.D., Goto, B.T., Sieverding, E., 2011. Glomeromycota: three new genera and glomoid species reorganized. Mycotaxon 116, 75-120.

Orcutt, D.M., Nilsen, E.T., 2000. The Physiology of Plants Under Stress. John Wiley and Sons, New York, NY (624 pp.).

Peterson, R.L., Farquhar, M.L., 1994. Mycorrhizas: integrated development between roots and fungi. Mycologia 86, 311-326.

Philippe, M., 2011. How many species of Araucarioxylon? Comptes Rendus Palevol 10, 201-208.

Phipps, C.J., Taylor, T.N., 1996. Mixed arbuscular mycorrhizae from the Triassic of Antarctica. Mycologia 88, 707-714

Pigg, K.B., Taylor, T.N., 1993. Anatomically preserved Glossopteris stems with attached leaves from the Central Transantarctic Mountains, Antarctica. American Journal of Botany 80, 500-516.

Pirozynski, K.A., Malloch, D.W., 1975. The origin of land plants: a matter of mycotrophism. Biosystems 6, 153-164.

Redecker, D., Raab, P., 2006. Phylogeny of the Glomeromycota (arbuscular mycorrhizal fungi): recent developments and new gene markers. Mycologia 98, 885-895.

Remy, W., Taylor, T.N., Hass, H., Kerp, H., 1994. Four hundred-million-year-old vesicular arbuscular mycorrhizae. Proceedings of the National Academies of the United States 91, 11841-11843.

Rößler R., Philippe M., Van Konijnenburg-van Cittert J.H.A., McLoughlin S., Sakala J., Zijlstra G., in press. (Coordinating authors) and 35 others. Which name(s) should 
be used for Araucaria-like fossil wood? - Results of a poll. Taxon xx, xxx-xxx. Accepted 19.11.12.

Rothwell, G.W., Basinger, J.F., 1979. Metasequoia milleri n. sp., anatomically preserved pollen cones from the Middle Eocene (Allenby Formation) of British Columbia. Canadian Journal of Botany 75, 958-970.

Ryberg, P.E., 2009. Reproductive diversity of Antarctic glossopterid seed-ferns. Review of Palaeobotany and Palynology 158, 167-179.

Ryberg, P.E., Taylor, E.L., Taylor, T.N., 2012. Antarctic glossopterid diversity on a local scale: the presence of multiple megasporophyll genera, Upper Permian, Mt. Achernar, Transantarctic Mountains, Antarctica. American Journal of Botany 99, $1531-1540$.

Schopf, J.M., 1970. Petrified peat from a Permian coal bed in Antarctica. Science 169, 274-277.

Schüßler, A., Walker, C., 2011. Evolution of the "Plant-Symbiotic" Fungal Phylum, Glomeromycota. In: Poggeler, S., Wostemeyer, J. (Eds.), The Mycota XIV. SpringerVerlag, Berlin Heidelberg, pp. 163-185.

Schüßler, A., Schwarzott, D., Walker, C., 2001. A new fungal phylum, the Glomeromycota: phylogeny and evolution. Mycological Research 105, 1413-1421.

Schwarzott, D., Walker, C., Schüßler, A., 2001. Glomus, the largest genus of the arbuscular mycorrhizal fungi (Glomales), is monmonophyletic. Molecular Phylogenetics and Evolution 21, 190-197.

Schwendemann, A.B. Decombeix, A.L, Taylor, T.N., Taylor, E.L, Krings, M. 2011. Morphological and functional stasis in mycorrhizal root nodules as exhibited by a Triassic conifer. Proceedings of the National Academy of Sciences of the United States 108, 13630-13634

Selosse, M.A., Le Tacon, F., 1998. The land flora: a phototroph-fungus partnership? TRENDS in Ecology and Evolutionary Biology 13, 15-20.

Sengupta, A., Chaudhuri, S., 2002. Arbuscular mycorrhizal relations of mangrove plant community at the Ganges river estuary in India. Mycorrhiza 12, 169-174.

Simon, L., Bousquet, J., Levesque, R.C., Lalonde, M., 1993. Origin and diversification of endomycorrhizal fungi and coincidence with vascular land plants. Nature 363, 67-68.

Slater, B.J., McLoughlin, S., Hilton, J., 2012. Animal-plant interactions in a Middle Permian permineralised peat of the Bainmedart Coal Measures, Prince Charles Mountains, Antarctica. Palaeogeography Palaeoclimatology Palaeoecology 363-364, 109-126.

Smith, S.A., Read, D.J., 2008. Mycorrhizal Symbiosis, 3rd ed. Academic Press, Burlington, MA (800 pp.).

Smith, F.A., Smith, S.E., 1997. Structural diversity in (vesicular)-arbuscular mycorrhizal symbioses. New Phytologist 137, 373-388.

Stevens, K.J., Wellner, M.R., Acevedo, M.F., 2010. Dark septate endophyte and arbuscular mycorrhizal status of vegetation colonizing a bottomland hardwood forest after a 100 year flood. Aquatic Botany 92, 105-111.

Stockey, R.A., Rothwell, G.W., Addy, H.D., Currah, R.S., 2001. Mycorrhizal association of the extinct conifer Metasequoia milleri. Mycological Research 105, 202-205.

Strullu-Derrien, C., Strullu, D., 2007. Mycorrhization of fossil and living plants. Comptes Rendus Palevol 6, 483-494.
Stubblefield, S.P., Taylor, T.N., 1986. Wood decay in silicified gymnosperms from Antarctica. Botanical Gazette 147, 116-125.

Stubblefield, S.P., Taylor, T.N., Trappe, J.M., 1987a. Fossil mycorrhizae: a case for symbiosis. Science 237, 59-60.

Stubblefield, S.P., Taylor, T.N., Trappe, J.M., 1987b. Vesicular-arbuscular mycorrhizae from the Triassic of Antarctica. American Journal of Botany 74, 1904-1911.

Stürmer, S.L., 2012. A history of the taxonomy and systematics of arbuscular mycorrhizal fungi belonging to the phylum Glomeromycota. Mycorrhiza 22, 247-258.

Tawaraya, K., Takaya, Y., Turjaman, M., Tuah, S.J., Limin, S.H., Tamai, Y., Cha, J.Y., Wagatsuma, T., Osaki, M., 2003. Arbuscular mycorrhizal colonization of tree species grown in peat swamp forests of Central Kalimantan, Indonesia. Forest Ecology and Management 182, 381-386.

Taylor, T.N., Taylor, E.L., 1987. Structurally preserved fossil plants from Antarctica. III. Permian seeds. American Journal of Botany 74, 903-913.

Taylor, T.N., Krings, M., 2005. Fossil microorganisms and land plants: associations and interactions. Symbiosis 40, 119-135.

Taylor, E.L., Ryberg, P.E., 2007. Tree growth at polar latitudes based on fossil tree ring analysis. Palaeogeography Palaeoclimatology Palaeoecology 225, 246-264.

Taylor, T.N., Taylor, E.L., 1997. The distribution and interactions of some Paleozoic fungi. Review of Palaeobotany and Palynology 95, 83-94.

Taylor, E.L., Taylor, T.N., Collinson, J.W., 1989a. Depositional setting and paleobotany of Permian and Triassic permineralized peat from the Central Transantarctic Mountains. International Journal of Coal Geology 12, 657-679.

Taylor, T.N., Taylor, E.L., Isbell, J.L., 1989b. Glossopterid reproductive organs from Mount Achernar, Antarctica. Antarctic Journal of the United States 24, 28-30.

Taylor, T.N., Remy, W., Hass, H., Kerp, H., 1995. Fossil arbuscular mycorrhizae from the Early Devonian. Mycologia 87, 560-573.

Taylor, T.N., Taylor, E.L., Krings, M., 2009. Paleobotany: The Biology and Evolution of Fossil Plants, 2nd ed. Academic Press, Burlington, MA (1252 pp.).

Toljander, J.F., Artursson, V., Paul, L.R., Jansson, J.K., Finlay, R.D., 2006. Attachment of different soil bacteria to arbuscular mycorrhizal fungal extraradical hyphae is determined by hyphal vitality and fungal species. FEMS Microbiology Letters 254, 34-40.

Wang, B., Qiu, Y.L., 2006. Phylogenetic distribution and evolution of mycorrhizas in land plants. Mycorrhiza 16, 299-363.

Wang, B., Yeun, L.H., Xue, J.-Y., Liu, Y., Ané, J.-M., Qiu, Y.-L., 2010. Presence of three mycorrhizal genes in the common ancestor of land plants suggests a key role of mycorrhizas in the colonization of land by plants. New Phytologist 186, 514-525.

Weaver, L., McLoughlin, S., Drinnan, A.N., 1997. Fossil woods from the Upper Permian Bainmedart Coal Measures, northern Prince Charles Mountains, East Antarctica. AGSO Journal of Australian Geology and Geophysics 16, 655-676.

Wu, B., Isobe, K., Ishii, R., 2004. Arbuscular mycorrhizal colonization of the dominant plant species in primary successional volcanic deserts on the Southeast slope of Mount Fuji. Mycorrhiza 14, 391-395.

Wubet, T., Kottke, I., Teketay, D., Oberwinkler, F., 2003. Mycorrhizal status of indigenous trees in dry Afromontane forests of Ethiopia. Forest Ecology and Management 179, 387-399. 